\title{
Inhibition of copper local depassivation in alkaline media with oxygen-containing anions
}

\author{
E.A. Skrypnikova ${ }^{1}$ and S.A. Kaluzhina ${ }^{2}$ \\ ${ }^{1}$ MESC Air Force Military Air Academy named after N.E. Zhukovsky and Yu.A. Gagarin, \\ ul. Staryh bolshevikov 54a, Voronezh, 394000 Russian Federation \\ ${ }^{2}$ Voronezh State University, Universitetskaya pl. 1, Voronezh, 394006 Russian Federation \\ E-mail: kaluzhina@vmail.ru
}

\begin{abstract}
Using complex physical and chemical methods, a comparative estimation of the capability of benzotriazole (BTAH) to act as an inhibitor of copper local activation (LA) was carried out in alkaline-nitrate and alkaline-sulphate solutions in a temperature range of $20-60^{\circ} \mathrm{C}$. It was shown that in both systems studied, BTAH hinders copper LA according to an adsorption-polymerization mechanism. Furthermore, the effect is the stronger, the higher the temperature of the working solution is.
\end{abstract}

Key words: copper, pitting corrosion, elevated temperature, benzotriazole.

Received: February 12, 2017. Published: April 03, 2017.

doi: $10.17675 / 2305-6894-2017-6-2-4$

\section{Introduction}

It is known that in heat exchange and water supply systems, copper that has a high general corrosion resistance, undergoes various types of dangerous local destruction. Taking into account that equipment in systems of this type often work on the closed cycle principle, among the protection methods it is expedient to analyze the capability of water-soluble inhibitors to affect the media corrosiveness. In the present work, we chose benzotriazole well studied in the practice of metal protection against general corrosion in acidic and neutral media. At the same time, the use of BTAH as a metal local activation inhibitor in alkaline solutions is rarely covered in the literature. In view of this, the aim of this study was to find out the possibility of BTAH application as a copper LA inhibitor in alkaline media containing nitrate and sulfate ions under various temperatures.

\section{Experimental}

The experiments were carried out in a glass three electrode electrolytic cell ( $V=$ $0.250 \mathrm{dm}^{3}$ ) with non-separated cathodic and anodic spaces. A copper plate (M1, $99.9 \mathrm{wt} \%$ $\mathrm{Cu}$ ) mounted in epoxy resin and having a working surface of $S=7.85 \times 10^{-5} \mathrm{~m}^{2}$ played the role of the electrode. A silver chloride electrode $(E=0.200 \mathrm{~V}$ (NHE)) was used as the reference electrode, which was connected to the working electrode through a salt bridge 
filled by a working solution and having a Haber-Luggin capillary at the end. A platinum counter electrode was used.

Two systems were chosen as the background electrolytes: I $-1 \times 10^{-2} \mathrm{M} \mathrm{NaOH}+$ $1 \times 10^{-2} \mathrm{M} \mathrm{NaNO}_{3}$ and II $-1 \times 10^{-2} \mathrm{M} \mathrm{NaOH}+1 \times 10^{-2} \mathrm{M} \mathrm{Na}_{2} \mathrm{SO}_{4}$ (pH 12). According to literature data $[1,2]$ confirmed by our own experimental data [3], copper undergoes local activation in the background electrolytes. The BTAH concentrations in the system were varied from $1 \times 10^{-7}$ to $1 \times 10^{-2} \mathrm{M}$. All electrolytes were prepared from analytical grade chemicals using distilled water. The studies were carried out in the temperatures range from 20 to $60^{\circ} \mathrm{C}$. In the experiments at elevated temperatures, the electrolytic cell was placed in an LW-4 water bath (the temperature in the latter was maintained to within $\pm 1^{\circ} \mathrm{C}$ ) [4]. The working cell temperature was monitored with a mercury thermometer.

The following physicochemical methods were used to obtain systematic and valid experimental data: inversion voltammetry (IVA), cyclic voltammetry (CVA), chronoamperometry, and microscopy methods. The studies were carried out using a P$5827 \mathrm{M}$ potentiostat and a potential scan rate of $0.2 \mathrm{~V} / \mathrm{min}$ according to the standard technique described in [5]. Monitoring of the copper surface before and after the experiment was performed using the microscopes: MBS-2 ( $\times 7$ magnification) and MIM-7 ( $\times 500$ magnification). Additional studies were carried out using a JEOL $6380 \mathrm{LV}$ scanning electron microscope equipped with an EDS INCA 250 energy-dispersive unit to estimate the qualitative and quantitative composition of the products on the copper surface.

Prior to each experiment, the surface of the electrode was polished with abrasive papers with gradually decreasing grain size, degreased with alcohol, rinsed with distilled water, and dried with filter paper. After being dipped in the electrolyte, the electrode underwent cathodic pre-polarization $(E=-1.000 \mathrm{~V} ; \tau=10 \mathrm{~min})$ to rebuild the natural oxide films and reproduce the initial copper surface, and then the electrode was studied by the potentiodynamic method (recording of IVA or CVA curves in the potential range from -1.000 to $+0.800 \mathrm{~V})$. The electrode potential was always recalculated versus normal hydrogen electrode (NHE).

\section{Results and discussion}

The results obtained (Tables 1,2) show that BTAH addition in background electrolytes (Figures 1,2), results in gradual copper LA supression. On achieving $C_{\mathrm{BTAH}}=2 \times 10^{-5} \mathrm{M}$ (system I) and $C_{\mathrm{BTAH}}=8 \times 10^{-4} \mathrm{M}$ (system II), the metal acquires the stable passive state, which is retained at higher BTAH concentrations. In this state, independence of current density on potential is observed on the anodic part of the voltamogramm in a wide potential range (Figures 3,4), while the chronoamperograms obtained at this region have a typical dropping shape. The latter confirms the conclusion made above. 
Table 1. Effect of BTAH concentration on copper $\mathrm{LA}$ in $1 \times 10^{-2} \mathrm{M} \mathrm{NaOH}+1 \times 10^{-2} \mathrm{M} \mathrm{NaNO}_{3}\left(\mathrm{Na}_{2} \mathrm{SO}_{4}\right)+$ $x \mathrm{M}$ BTAH at $20^{\circ} \mathrm{C}$.

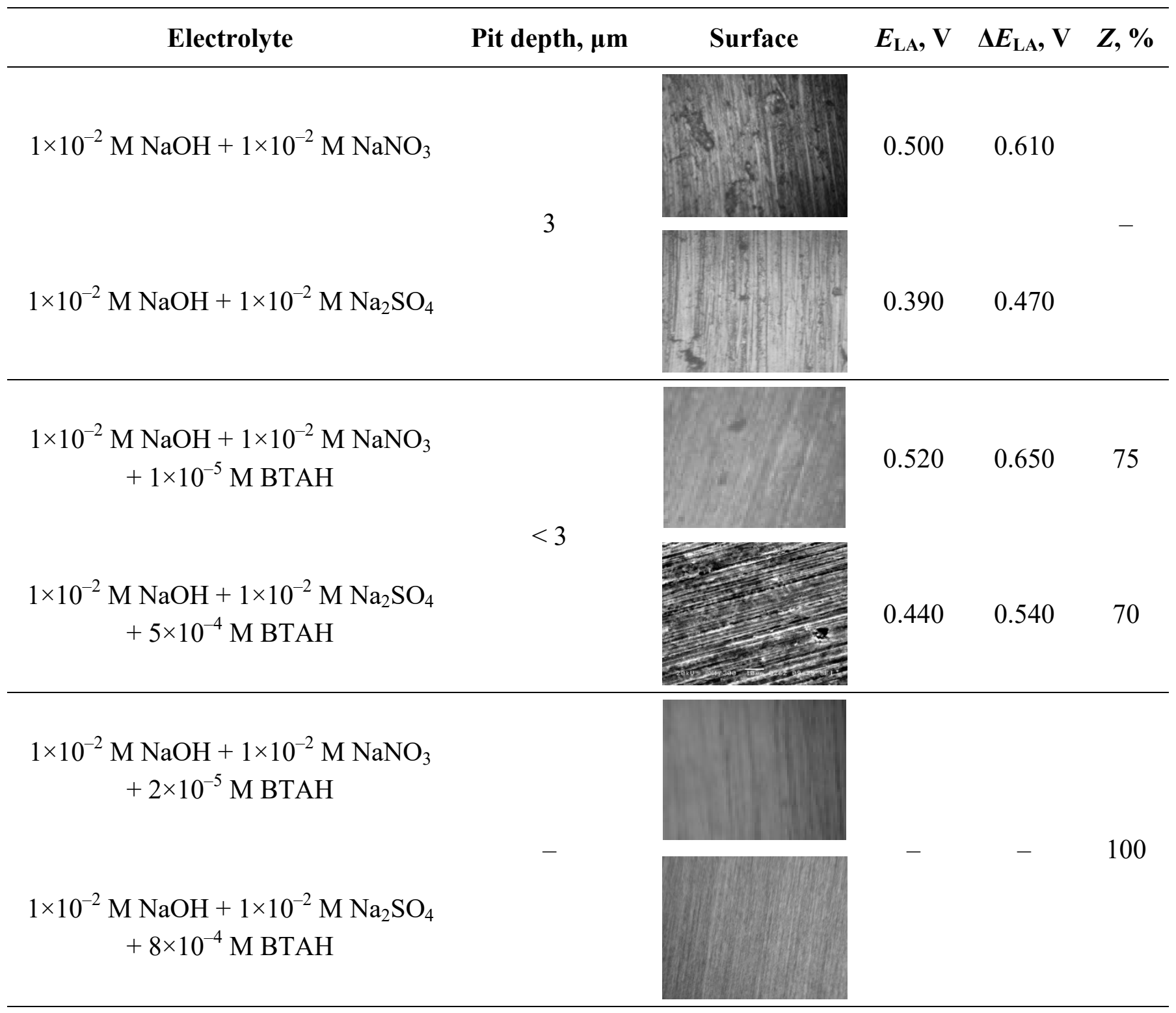

A quantitative estimation of BTAH efficiency as a copper LA inhibitor was made by two independent methods using data about the LA induction period $\left(\tau_{\text {ind }}\right)$. Taking into account that under the conditions of interest, $1 / \tau_{\text {ind }}$ is a criterion of LA rate, the protection coefficient ( $Z$ ) was calculated according to classical Equation (1) [3].

$$
Z=\frac{\left(1 / \tau_{\text {ind }}\right)_{0}-\left(1 / \tau_{\text {ind }}\right)_{\text {inh }}}{\left(1 / \tau_{\text {ind }}\right)_{0}} \times 100 \%,
$$


where $\left(1 / \tau_{\text {ind }}\right)_{0}$ and $\left(1 / \tau_{\text {inh }}\right)_{\text {inh }}$ are LA rate of copper in the background electrolyte and in the presence of the inhibitor, respectively.

Table 2. The nature and quantitative ratio of elements present in the copper surface film after chronoamperometric studies at $E_{\mathrm{LA}}$ in the solutions at $20^{\circ} \mathrm{C}$.

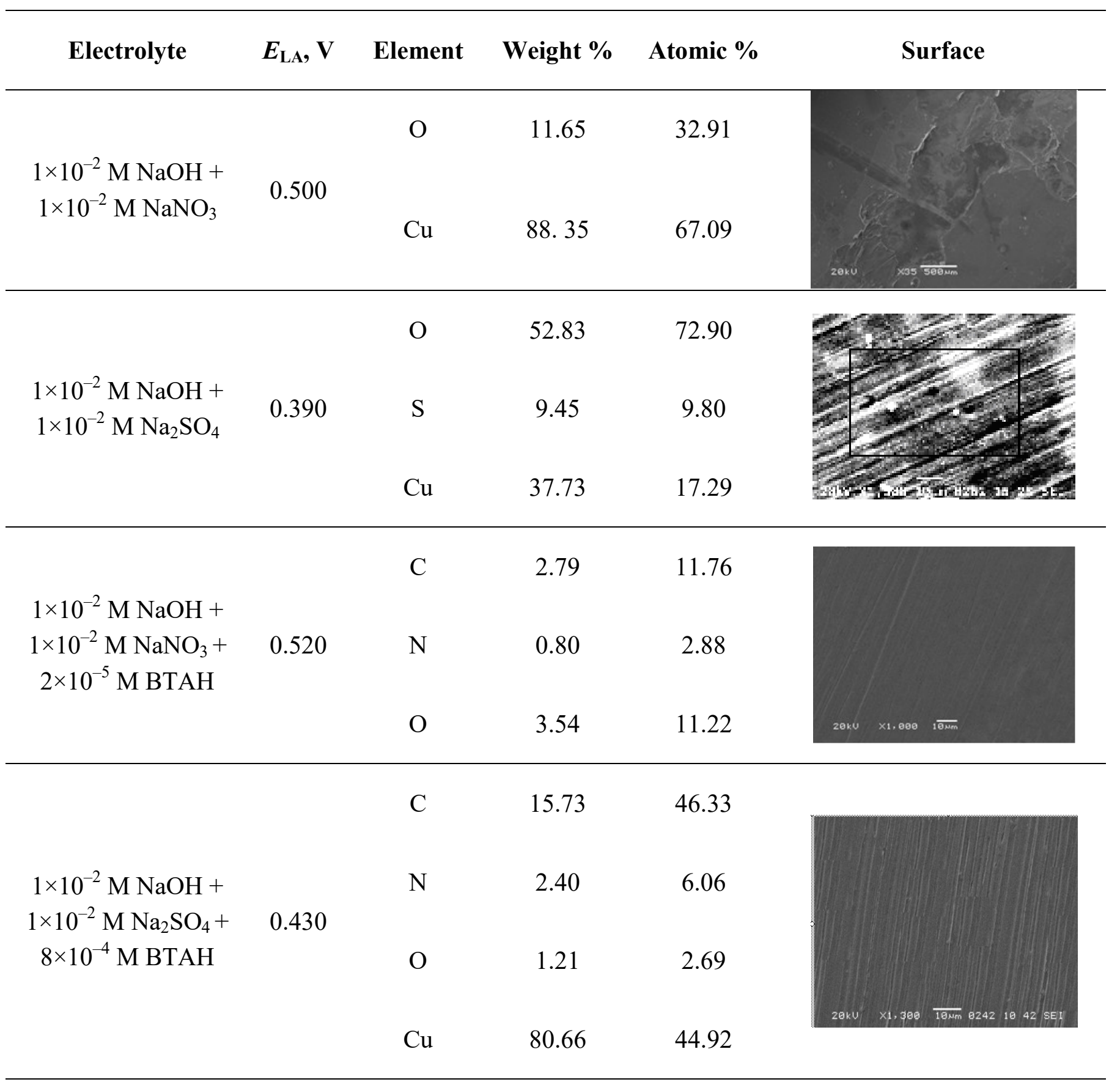




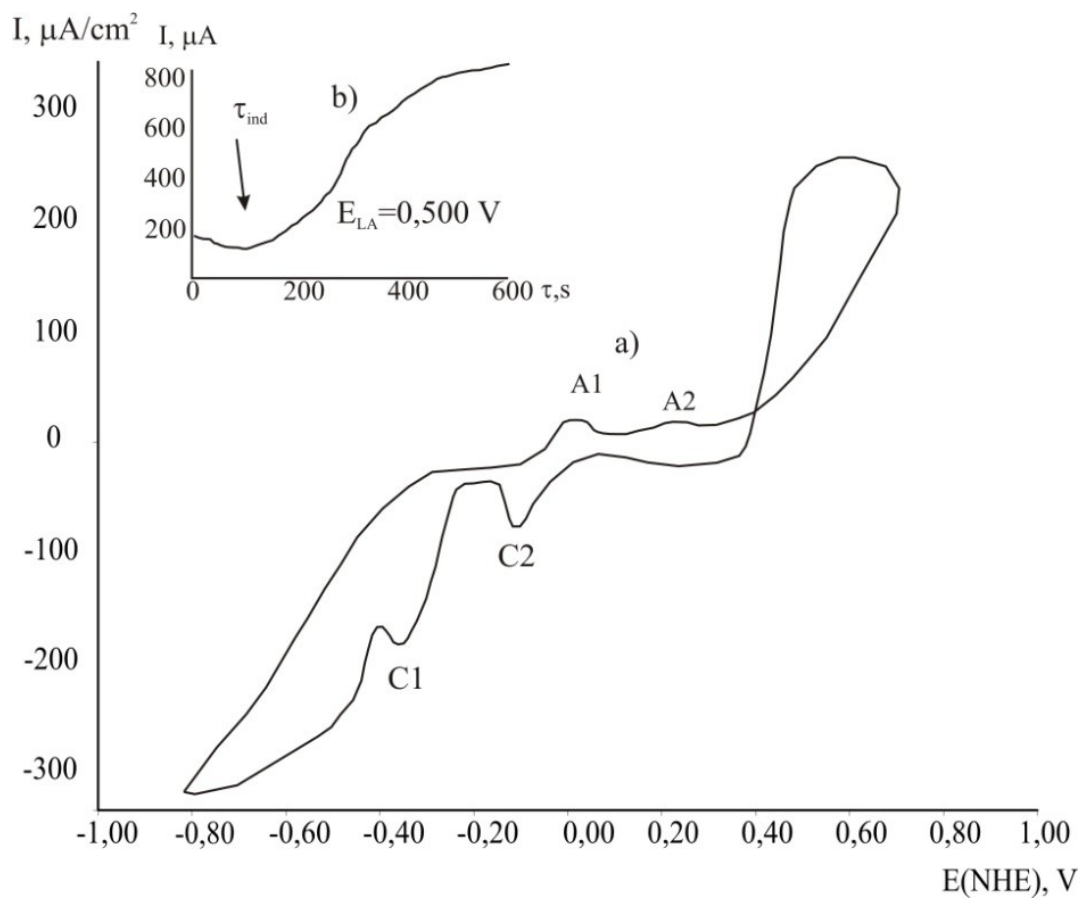

Figure 1. (a) A CVA curve of copper in $1 \times 10^{-2} \mathrm{M} \mathrm{NaOH}+1 \times 10^{-2} \mathrm{M} \mathrm{NaNO}_{3}$ solution at $20^{\circ} \mathrm{C}$, where $\mathrm{A} 1 / \mathrm{C} 1$ indicate $\mathrm{Cu} / \mathrm{Cu}_{2} \mathrm{O}, \mathrm{A} 2 / \mathrm{C} 2$ indicate $\mathrm{Cu}_{2} \mathrm{O} / \mathrm{CuO}, \mathrm{Cu}(\mathrm{OH})_{2}$; (b) a chronoamperogram at $E_{\mathrm{LA}}=0.500 \mathrm{~V}$.

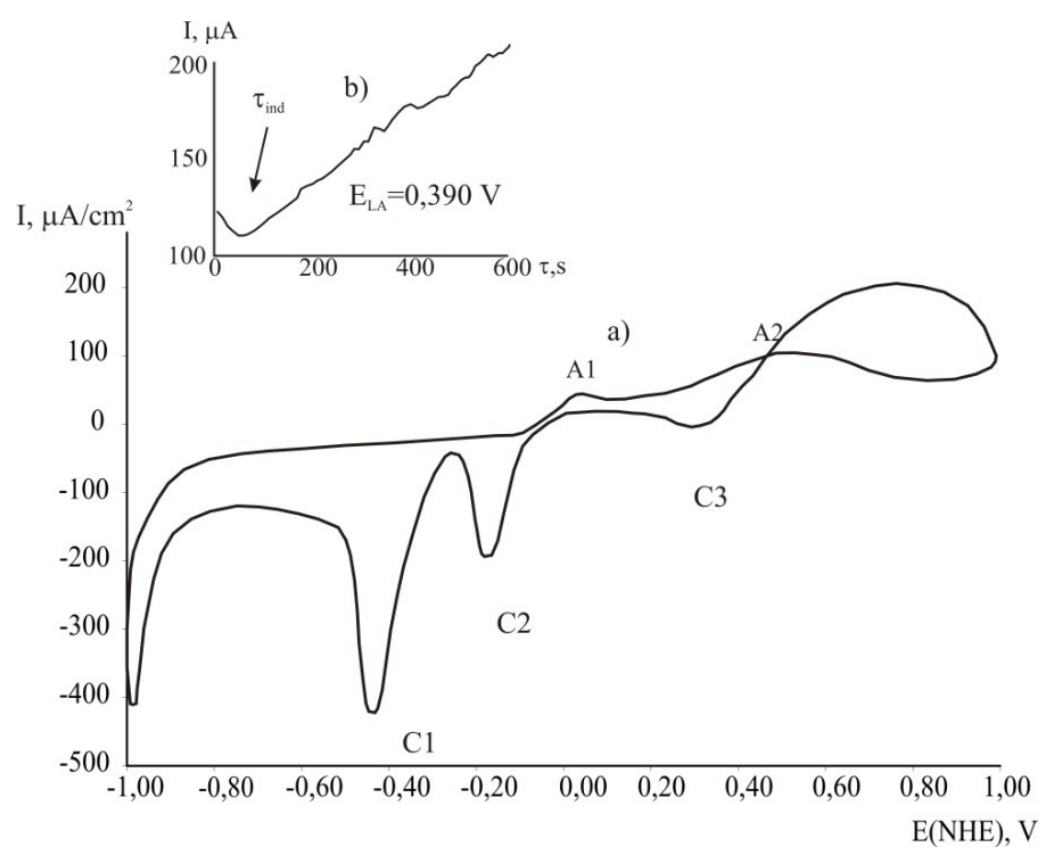

Figure 2. (a) A CVA curve of copper in $1 \times 10^{-2} \mathrm{M} \mathrm{NaOH}+1 \times 10^{-2} \mathrm{M} \mathrm{Na}_{2} \mathrm{SO}_{4}$ solution at $20^{\circ} \mathrm{C}$, where $\mathrm{A} 1 / \mathrm{C} 1$ indicate $\mathrm{Cu} / \mathrm{Cu}_{2} \mathrm{O}, \mathrm{A} 2 / \mathrm{C} 2$ indicate $\mathrm{Cu}_{2} \mathrm{O} / \mathrm{CuO}, \mathrm{Cu}(\mathrm{OH})_{2}$; (b) a chronoamperogram at $E_{\mathrm{LA}}=0.390 \mathrm{~V}$. 


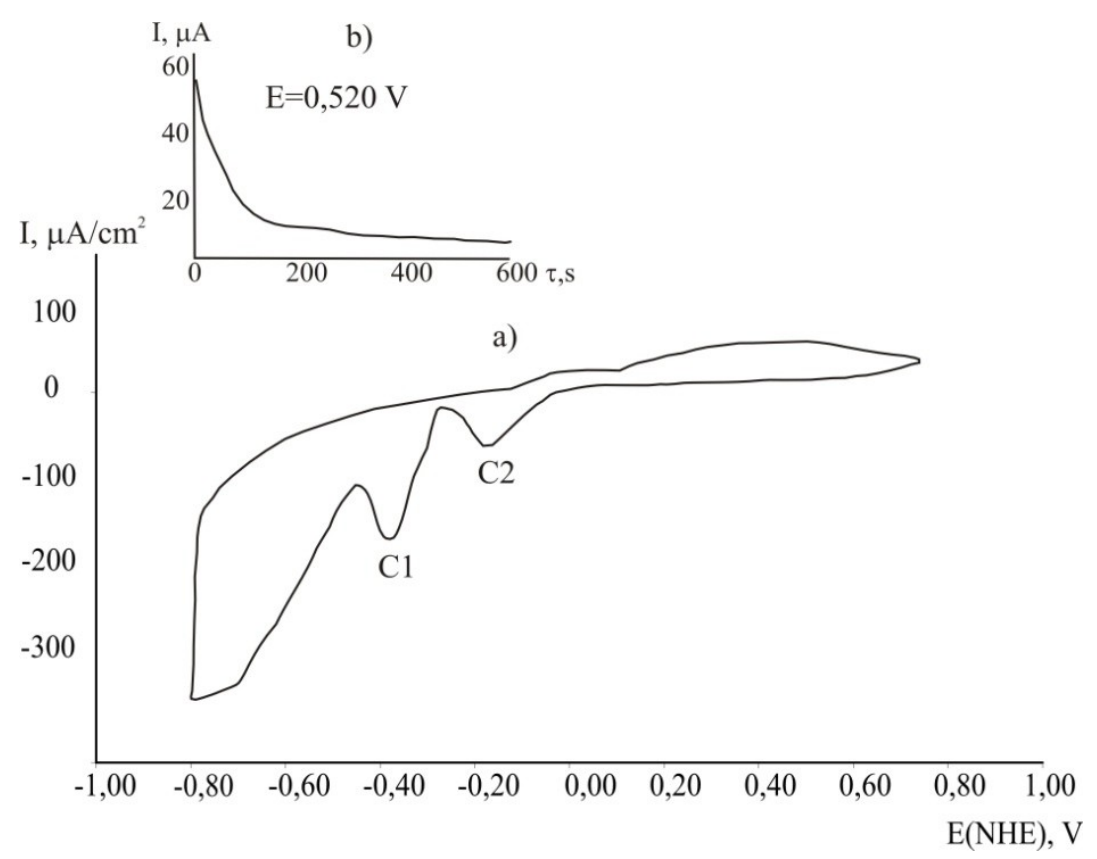

Figure 3. (a) A voltammogram of $\mathrm{Cu}$ in $1 \times 10^{-2} \mathrm{M} \mathrm{NaOH}+1 \times 10^{-2} \mathrm{M} \mathrm{NaNO}_{3}+2 \times 10^{-5} \mathrm{M}$ $\mathrm{BTAH}$ at $20^{\circ} \mathrm{C}$, (b) a chronoamperogram recorded in the LA region in the background solution (at $E=0.520 \mathrm{~V}$ ).

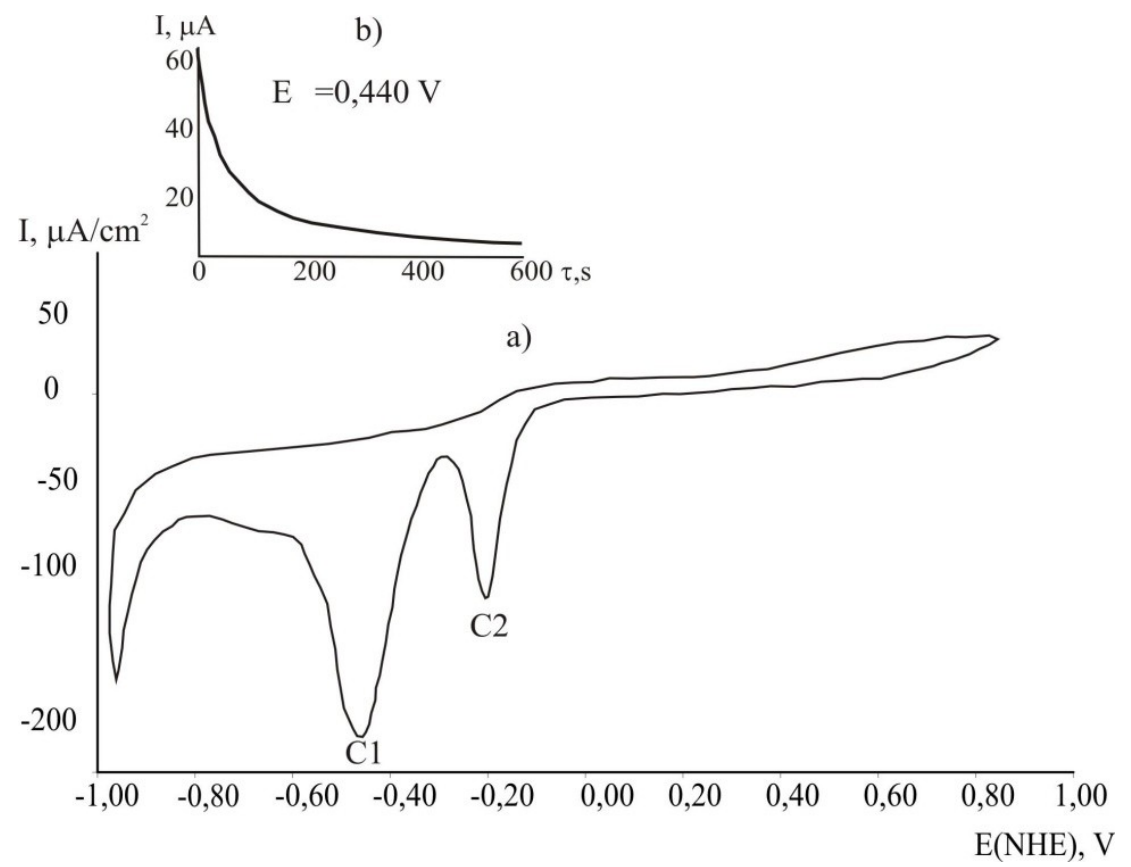

Figure 4. (a) A voltammogram of $\mathrm{Cu}$ in $1 \times 10^{-2} \mathrm{M} \mathrm{NaOH}+1 \times 10^{-2} \mathrm{M} \mathrm{Na}_{2} \mathrm{SO}_{4}+8 \times 10^{-4} \mathrm{M}$ $\mathrm{BTAH}$ at $20^{\circ} \mathrm{C}$, (b) a chronoamperogram recorded in the LA region in the background solution (at $E=0.440 \mathrm{~V}$ ). 
According to experimental data (Table 2), the $Z$ value raises upon BTAH concentration increase in both systems studied and reaches $100 \%$ at boundary inhibitor concentrations $\left(C_{\mathrm{BTAH}}=2 \times 10^{-5} \mathrm{M}\right.$ (system I) and $C_{\mathrm{BTAH}}=8 \times 10^{-4} \mathrm{M}$ (system II), respectively).

In addition to electrochemical studies, for control purposes, the composition of the products on the copper electrode surface after the experiments was studied by SEM combined with an EDS INCA 250 energy-dispersive unit (Table 2). Analysis of the results obtained permits us to conclude that addition of BTAH to an alkaline nitrate electrolyte results in nitrogen appearance on the oxidized copper surface, in contrast to the copper surface in the background electrolyte. The $\mathrm{N}$ content increases with an increase in the BTAH concentration. It indirectly confirms that protective copper benzotriazolate compounds are present on the electrode surface.

In the alkaline sulphate solution, the presence of BTAH results in a decrease in the amount of sulphur on the copper surface, whereas $\mathrm{C}$ and $\mathrm{N}$ simultaneously appear on the surface. In this case, the atomic and weight percentage of $\mathrm{C}$ and $\mathrm{N}$ increases in parallel with a decrease in the S element content with an increase in the BTAH concentration. The observation of $\mathrm{C}$ and $\mathrm{N}$ elements, which are parts of the BTAH molecule, on the metal surface and the strong dependence of their quantity on the inhibitor concentration possibly indicate the existence of copper benzotriazolate protective compounds on the metal surface.

At an elevated temperature, the BTAH efficiency in both systems studied increases and at $60^{\circ} \mathrm{C}$ the smallest inhibitor concentration is required for LA supression (Table 3 ).

Table 3. Dependence of the BTAH concentration boundary on temperature in $1 \times 10^{-2} \mathrm{M} \mathrm{NaOH}+1 \times 10^{-2} \mathrm{M}$ $\mathrm{NaNO}_{3}\left(\mathrm{Na}_{2} \mathrm{SO}_{4}\right)+x \mathrm{M}$ BTAH solution

\begin{tabular}{ccccc}
\hline $\boldsymbol{t},{ }^{\circ} \mathbf{C}$ & $\mathbf{2 0}$ & $\mathbf{4 0}$ & $\mathbf{5 0}$ & $\mathbf{6 0}$ \\
\hline $\begin{array}{c}+x \mathrm{M} \mathrm{BTAH} \\
+\end{array}$ & $2 \times 10^{-5}$ & $5 \times 10^{-6}$ & $4 \times 10^{-6}$ & $8 \times 10^{-7}$ \\
$\begin{array}{c}1 \times 10^{-2} \mathrm{M} \mathrm{NaOH}+1 \times 10^{-2} \mathrm{M} \mathrm{Na}_{2} \mathrm{SO}_{4} \\
+x \mathrm{M} \mathrm{BTAH}\end{array}$ & $8 \times 10^{-4}$ & $2 \times 10^{-6}$ & $2 \times 10^{-6}$ & $5 \times 10^{-7}$ \\
\hline
\end{tabular}

It is known [7] that the protective action of BTAH is due to its high adsorption ability and formation of a dense (in alkaline media), poorly soluble, stable copper benzotriazolate film on the metal surface. On the one hand, this film $[\mathrm{Cu}(\mathrm{I})-\mathrm{BTA}]$ is a physical barrier screening the metal surface from the corrosive ions present in solution, and on the other hand, it binds copper atoms, preventing anodic dissolution and decreasing the electrical conductivity of the surface layer [7]. The following reactions [7-10] describe the interaction of BTAH and copper surface in alkaline media:

$$
\mathrm{Cu}+\mathrm{BTA}^{-} \rightarrow \mathrm{Cu}: \mathrm{BTA}_{\mathrm{ads}}^{-}
$$




$$
\mathrm{Cu}+\mathrm{BTA}^{-} \rightarrow \mathrm{Cu}(\mathrm{I})-\mathrm{BTA}+\mathrm{e}^{-}
$$

Reaction (2) corresponds to the $\mathrm{BTA}^{-}$adsorption on the copper surface. Reaction (3) is related to the chemical formation of the $[\mathrm{Cu}(\mathrm{I})-\mathrm{BTA}]$ complex, which subsequently forms mono- and poly-layer structures, depending on the experiment conditions.

Thus, experiments demonstrate that BTAH can be used as an efficient copper LA inhibitor in alkaline-nitrate and alkaline-sulphate solutions at $20^{\circ} \mathrm{C}$. However, while small BTAH concentrations just slow down copper LA due to the formation of a protective complex with a low polymerization degree from the metal and benzotriazole [11], copper is not subject to local destruction at $C_{\mathrm{BTAH}} \geq 2 \times 10^{-5} \mathrm{M}$ in alkaline-nitrate solutions and at $C_{\mathrm{BTAH}} \geq 8 \times 10^{-4} \mathrm{M}$ in alkaline-sulphate solutions owing to the formation of a dense protective film that is impenetrable for corrosive ions.

The inhibitor efficiency increase with a temperature raise is probably due to an increase in the polymerization degree of the protective complex [11]. Simultaneously, the share of oxide-hydroxide products on the metal surface increases with a temperature raise. It also promotes the stabilization of the copper triazolate protective film due to the presence of chemical $\mathrm{Cu}-\mathrm{N}$ bonds as well as hydrogen bonds between the oxygen in the copper oxide and hydrogen in the benzene ring $(\mathrm{C}-\mathrm{H})$ of the benzotriazole molecule [9].

\section{Conclusion}

1. Using a combination of electrochemical and physicochemical methods, comparative data on the regularities of copper local activation in alkaline-nitrate and alkalinesulphate solutions in the presence of benzotriazole $\left(1 \times 10^{-7} \leq \mathrm{C}_{\mathrm{BTAH}} \leq 1 \times 10^{-2} \mathrm{M}\right)$ at temperatures of $20-60^{\circ} \mathrm{C}$ have been obtained.

2. It has been shown that BTAH is an effective inhibitor of copper LA in both investigated systems.

3. At $20^{\circ} \mathrm{C}$, full copper protection against $\mathrm{LA}$ is achieved at $C_{\mathrm{BTAH}}=2 \times 10^{-5} \mathrm{M}$ in alkalinenitrate electrolytes and at $C_{\mathrm{BTAH}}=8 \times 10^{-4} \mathrm{M}$ in alkaline-sulphate electrolytes.

4. At the same time, the inhibitor is more effective in these solutions at $60^{\circ} \mathrm{C}$ : the metal local destruction process stops at concentrations by two orders lower than at $20^{\circ} \mathrm{C}$, namely, $C_{\mathrm{BTAH}}=8 \times 10^{-7} \mathrm{M}$ in the alkaline-nitrate electrolyte and at $C_{\mathrm{BTAH}}=5 \times 10^{-7} \mathrm{M}$ in the alkaline-sulphate electrolyte.

\section{Acknowledgements}

This study was supported by the Ministry of Education and Science of the Russian Federation (Project RNP 08-03-00194).

\section{References}

1. Uhlig's Corrosion Handbook, Ed. R.W. Revie, Wiley, 2000.

2. H. Kaesche, Corrosion of metals, Springer-Verlag, Berlin, Heidelberg, New York, 1979. 
3. S.A. Kaluzhina and I.V. Kobanenko, Zashch. Met., 2008, 37, 266 (in Russian).

4. N.E. Homutov, Electromotive forces, electrode potentials and chemical equilibriums, Moscow, Khimiya, 1971 (in Russian).

5. E.A. Skrypnikova, S.A. Kaluzhina and E.V. Popova, Korroz.: mater., zashch., 2008, 11, 1 (in Russian).

6. I.L. Rozenfeld, Ingibitory korrozii (Corrosion inhibitors), 1977, Moscow, Khimiya (in Russian).

7. D. Tromans and R. Sun, J. Electrochem. Soc., 1991, 138, 3235.

8. N. Tantavichet and M. Pritzker, J. Appl. Electrochem., 2006, 36, 49.

9. Y. Hong, V.K. Devarapalli, D. Roy and S.V. Babu, J. Electrochem. Soc., 2007, 154, H444.

10. K.L. Stewart, J. Zhang, S. Li, P.W. Carter and A.A. Gewirth, J. Electrochem. Soc., 2007, 154, D57.

11. V. Brusic, M.A. Frisch, B.N. Eldridge, F.P. Novak, F.B. Kaufman, B.M. Rush and G.S. Frankel, J. Electrochem. Soc., 1991, 138, no. 8, 2253. 